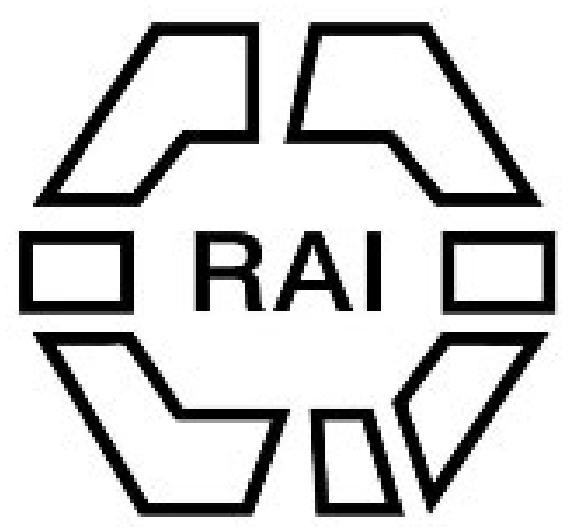

Note on Platform-Dwellings in Assam

Author(s): S. E. Peal

Source: The Journal of the Anthropological Institute of Great Britain and Ireland, Vol. 11 (1882), pp. 53-56

Published by: Royal Anthropological Institute of Great Britain and Ireland

Stable URL: http://www.jstor.org/stable/2841499

Accessed: 15/06/2014 04:36

Your use of the JSTOR archive indicates your acceptance of the Terms \& Conditions of Use, available at http://www.jstor.org/page/info/about/policies/terms.jsp

JSTOR is a not-for-profit service that helps scholars, researchers, and students discover, use, and build upon a wide range of content in a trusted digital archive. We use information technology and tools to increase productivity and facilitate new forms of scholarship. For more information about JSTOR, please contact support@jstor.org. 
The election of Professor George Dancer Thane was announced.

A number of rubbings taken from door-posts and window frames in New Zealand. were exhibited, and a letter on the subject from Professor Max Müller was read, upon which the Chairman and Mr. A. L. Lewis made some remarks.

The following Note, communicated to Dr. E. B. Tylor by Mr. L. E. Peal, of Sibsagor, Assam, was read by the Assistant Secretary :-

\section{Note on Platform-Dwellings in Assam.}

\section{By S. E. Pead, Esq.}

\section{[With Plates II and III.]}

A short note in "Nature," No. 572, of October 14, re the connection of Swiss châlets and pile platform-dwellings of the Lakes, induces me to send you a few little sketches of the pile platform-houses seen here, among the hill tribes of and around Assam to the north, east, and south.

I lately made enquiry especially as to why they built on piles, and the only answer was, "the land was so uneven." This, however, is a mistake, inasmuch as they do build thus on level land, and never entirely without piles.

It is noteworthy that all hill races, as far as I see, except the Khasias, build thus ; and the people from the hills, or races who have settled in the plains for two hundred, or even for five or six hundred years, keep to the custom. On the other hand, Aryans and semi-Aryans do not use piled dwellings hereabouts.

Fig. 1, Plate II, is an exact copy of a sketch of the Bor Muthun, skull house or morang. The centre line of posts projects through the ridge, a custom of some tribes only, and these posts are covered like the roof with toku palm leaf, or with another palm called jengo. The posts project so as to enable them to be lowered as the part in the ground decays. The roof comes so far down as to hide the walls of matted split bamboo, of which also the platform and floor are made; these are supported by cross pieces borne on saplings, posts, and bamboo uprights. Houses from 30 to 200 feet long, and from 20 to 35 feet wide, are often built part on the ground and part raised, with fire-places built up of stones. A notched log serves as a ladder, to get on the platform or visitor's end ; and in some tribes, I hear, the log is inverted if visitors are not desired, equivalent to the "Darwaza Band" of Bengal. In no case are the platform posts in water, for all the changs or villages are perched on hill tops. 


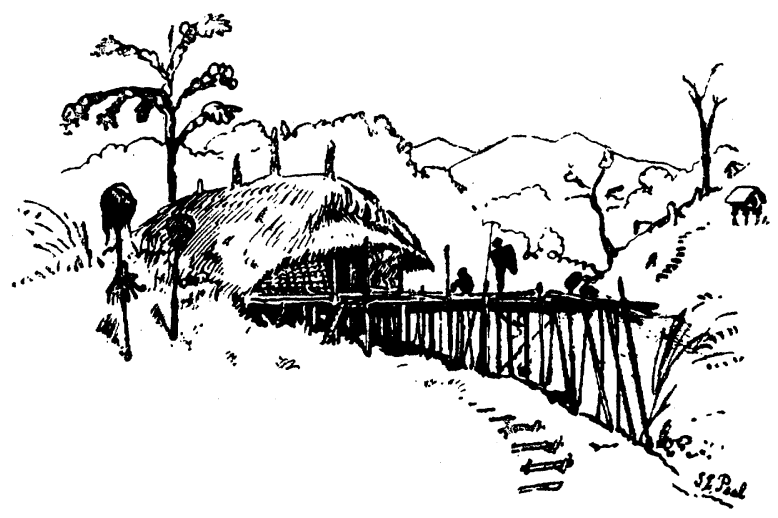

FIG. 1.

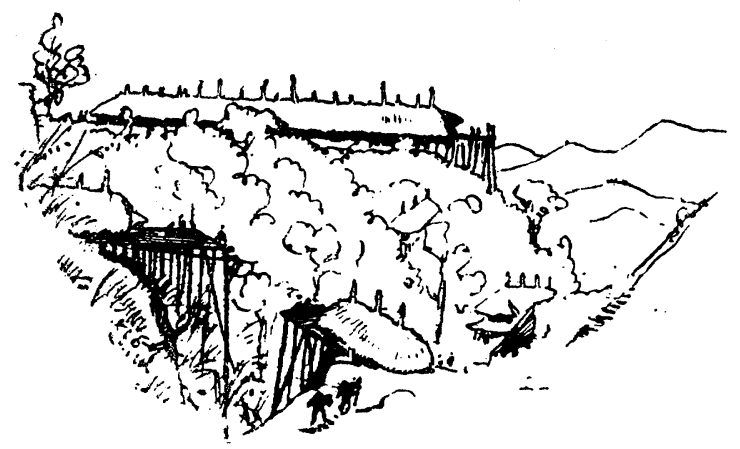

FrG. 2. 


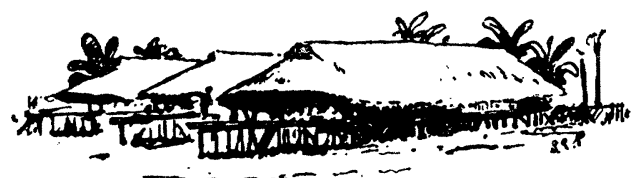

Fig. 1.

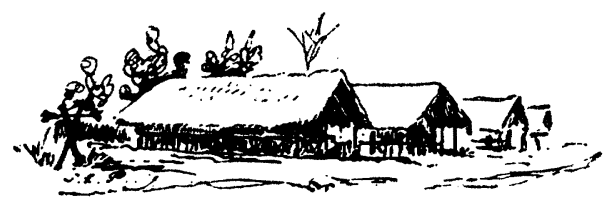

FIG. 2.

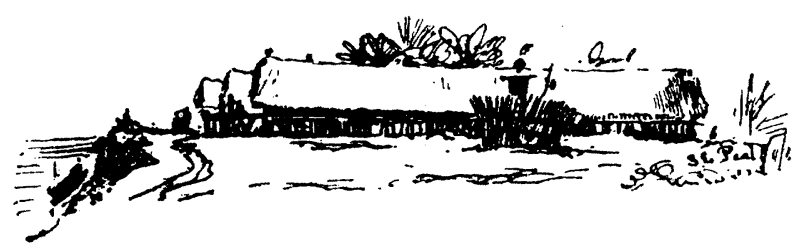

Fre. 3.

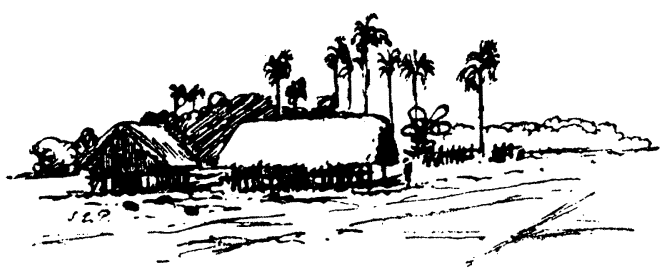

FIG. 4,

PLATFORM DWELLINGS, ASSAM. 
In fig. 1 the skulls of those taken in raids or by surprise are first exposed on stakes, and then when clean put in the frame seen in the front of the house.

Part of the platform is under a curved roof at the end of the house roof, and this is no doubt made so here to protect visitors from rain. They often sit out on it, and here, too, they dry grain, flesh, fish, \&c., so as to be out of the reach of the pigs and goats, so generally kept by all races having the platformhouses.

In fig. 2 is seen the extreme to which they at times go-in building over steep slopes-and the length of the houses of their headmen. This house is 200 feet long.

Fig. 1, Plate III, is from a sketch from nature, of Kamti houses at Jusa or "Bor Phakial," a Kamti village on Diking river, above Jaipur, East Assam, the people of which are Budhists, and of Shan origin. 'The ends you will observe have the curved part much developed, and under it the women weave and make pottery. As a rule, the Kamti houses are on level land and above all water. They keep pigs and goats underneath, the floor being 4 to 5 feet high.

Fig. 2 represents the Singphu houses, where the house-roof extends over and beyond the platform, and in this space cattle are tied or enclosed at night.

Fig. 3 shows the Miri houses, in lines also or rows, near river banks, north and north-east of Assam. The platforms are raised some 3 feet, and partly covered by the house-roof. In some, the platform projects very little, and like figs. 1 and 2 these houses are in the plains, but at times the land is flooded by the rivers overflowing. These people also keep pigs and goats underneath.

Fig. 4 illustrates the manner in which the Deodhains build houses on piles. The platform also is not large, and is under the end of roof; they are lineal descendants of the Ahoms, and speak and write Ahom. A few hundred alone remain, and on the banks of or near the Disang river, Sibsagor, I hear their houses are like those of the Aitonias, near Golaghat.

I cannot say if the Bhutias, Lepchas, or Nipalis have platforms on piles, nor yet so far the Abors or Daflas.

If it turns out that all these semi-savage non-Aryan hill races north-east and south-east of Bengal are the remains of the preAryan inhabitants of the Gangetic basin, the Osurs and Demons of the Hindus, it is likely that pile platform-dwellings were common all over India at one time, as was Jhuming. 
Explanation of Plates II and III.

Fac-similes reduced by photography from the author's penand-ink sketches, illustrating various forms of platform-dwellings in Assam.

\section{Plate II.}

Fig. 1. Skull-house and Morang of the Bor Muthuns, Nogas (Nagas), South-East Assam.

Fig. 2. The long building, with projecting posts, is the house of Joboka, Noga Raja.

\section{Plate III.}

Fig. 1. Pile-houses of Kamtis, in the plains of Eastern Assam.

Fig. 2. Singphu pile-houses, Eastern Assam.

Fig. 3. Pile-houses of the Miris, containing several related families and a burial place. Plains of Northern and Eastern Assam, near rivers.

Fig. 4. Small pile-houses of the Deodhains and Aitonias, in Assam.

\section{Discussion.}

Colonel-Godwin-Austen said: I do not think there is any connection between lake dwellings and the building of houses on piles or platform-dwellings, of which Mr. Peal has given us a description. I think it far more likely that in the East they are the result of a people exposed to a damp climate, and one where the rains are excessive, and having the presence of bamboos and other material on the spot ready for their construction. In a hilly country a level floor is thus more easily obtained. The custom extends through the Dafla and Akha hills : westward it is confined to the Bhutias in the plains, who in the interior build fine houses of mud or stone, to the Mechis at the base of the Darjiling Hills, who are the most western race who do so, and they are closely allied to the Garos. The platform-houses of the Daflas are very long, and are inhabited by fifty to eighty men, women, and children.

There are two notable exceptions in the Anghami and Kutcha Nagas, and the Khasis, who all build with the floor of the house on the ground; but even some of the Khasi villages on the slopes and base of the hills, where the climate is exceedingly wet, build their houses raised above the ground.

Mr. KeANE remarked that there were few more interesting ethnological fields than Assam, which for ages had been the common battle-field of the Aryan and Mongoloid races. Hence a special value attached to ail such accurate information regarding the habits and customs of the inbabitants of this region as had been supplied 
by the paper just read. At the same time he could not attach so much importance as many ethnologists seemed to do to such a feature as that of pile dwellings. Nor could he agree with the author's suggestion that this custom was peculiar to the non-Aryan races. It arose chiefly from such natural causes as humidity of the soil, and the necessity of providing a refuge against wild beasts or hostile tribes. Hence wherever these conditions existed the practice was found to prevail from the remotest time, and altogether independently of racial affinities. When we remembered the prehistoric pile dwellings of the Swiss lakes, besides those not only of Assam but also of Camboja, Borneo, New Guinea, and many other widely separated regions, it seerned impossible to assuciate the custom with any questions of ethnical differences or affinities.

The following paper was read by the author, and illustrated by the exhibition of a large number of objects of ethnological interest brought by Colonel Woodthorpe from the Naga Hills :-

Notes on the Wild Tribes Inhabiting the so-Called Naga Hills, on our North. East Frontier of India. Part I. By Lieutenant-Colonel R. G. WoOdTHORPE, R.E.

[With Plates IV aNd V.]

In the limits of the necessarily short paper which I have the honour of reading to you to-night, it will be impossible to do much more than allude in the briefest way to the distinguishing and peculiar characteristics of the very many diverse tribes who inhabit the so-called Naga Hills on our north-east frontier of India. I do not intend to theorise to any great extent concerning the origin of these tribes. I leave this to abler and better-informed men than I am, my object being simply to assist them in forming their conclusions by stating what I know to be facts concerning the Nagas.

In the very interesting field of research afforded by the Naga Hills, I followed in the footsteps of Colonel Godwin-Austen, and I am fully sensible of the loss which science sustained by that officer's retirement from the field, and cannot but feel how much more valuable would have been the results of our operations in those hills had Colonel Godwin-Austen remained to conduct them to the end.

The Naga tribes inhabit the hills south-east of Assam, dividing that province from the north-west portion of the Burmese territory, and their country may be said roughly to lie between the parallels of $25^{\circ}$ and $28^{\circ}$ north latitude, and $93^{\circ}$ and 